Man and Nature

L'homme et la nature

\title{
A Community of Exiles: The Quakers in 18th-Century Literature and Society
}

\section{Hope Leith}

Volume 10, 1991

URI : https://id.erudit.org/iderudit/1012626ar

DOI : https://doi.org/10.7202/1012626ar

Aller au sommaire du numéro

Éditeur(s)

Canadian Society for Eighteenth-Century Studies / Société canadienne d'étude du dix-huitième siècle

ISSN

0824-3298 (imprimé)

1927-8810 (numérique)

Découvrir la revue

Citer cet article

Leith, H. (1991). A Community of Exiles: The Quakers in 18th-Century

Literature and Society. Man and Nature / L'homme et la nature, 10, 93-104.

https://doi.org/10.7202/1012626ar

Copyright (c) Canadian Society for Eighteenth-Century Studies / Sociéte canadienne d'étude du dix-huitième siècle, 1991
Ce document est protégé par la loi sur le droit d'auteur. L'utilisation des services d'Érudit (y compris la reproduction) est assujettie à sa politique d'utilisation que vous pouvez consulter en ligne.

https://apropos.erudit.org/fr/usagers/politique-dutilisation/ 


\section{A Community of Exiles: The Quakers in 18th-Century Literature and Society}

For us as for the 18th-century reader or spectator, the Quakers are both familiar and alien, a community of exiles. We recognize the clothing, the idiosyncrasies of speech and behaviour, or think we do, although we would be hardpressed to explain how Quakers differ from other independent sects. We know virtually nothing about their particular society in Restoration and 18th-century England, and can learn little from the traditional literary accounts.

The Quaker is a figure of fun, the canting hypocrite with his hat on, in English literature from the Restoration to the end of the 18th century. From this period we will be looking at Centlivre's A Bold Stroke for a Wife because it presents a Quaker family rather than an individual, and makes some attempt to depict the larger Quaker community. Further, it is a contemporary of what is perhaps the best-known portrait of Quakers in the literature of this period, certainly so to my fellow French scholars, Voltaire's Lettres philosophiques.

My intention is to examine these portrayals in the light of actual social history, to bring out the function and the treatment of Quakers in 18th-century England, and finally to discuss how and why these literary portraits, the only ones we normally consider, are no more than caricatures, illustrations in social polemics. The risk the 20th-century reader runs is that while we recognize the irony, we cannot reconstitute the reality so mocked. To balance, we need to make room for Quaker discourse, for those accounts of personal experience and non-hierarchical organization that challenge traditional values not only in the realm of religion, but also in economics, politics, and education. It is fundamental to Quakerism that there are no distinctions between secular and sacred, between clergy and lay. As such they were not only self-excluded from the English society of their time, but perpetually challenged its validity. They are no less a challenge to Voltaire's beliefs. He may welcome and praise their alternative social vision, their tolerance and lack of hierarchy. But he cannot do other than ridicule the personal and 
mystical relationship with God that underlies Quaker goals of social reform, given his own rationalism.

Quakers in the late 17th and early 18th centuries suffered very active persecution, both under the Commonwealth and continuing under the Restoration. During the Commonwealth period, 3 persons ( 2 men and 1 woman) were hanged for preaching Quakerism in Massachusetts. In 1662 an Act was passed in Britain specifically banning Quakerism. This oppression peaked shortly after the Restoration, with imprisonment and transportation being frequent. Meetings were illegal, and meetinghouses were routinely destroyed. Records kept by the Meeting for Sufferings list 21,000 Friends, not incidents, who were fined or imprisoned (many more than once). 450 Friends died in prison or as a result of bad treatment, including floggings. Isabel Grubb cites that in 1683, 178 Quakers in Bristol alone were fined a total of 16,440 pounds for non-attendance. ${ }^{1}$ Fines and distrainder of goods for non-payment of tithe or non-attendance of the Anglican church could further include destruction of the tools and shop (Grubb, pp. 109-110).

The attitude of the Quakers to their suffering is exemplified by a petition from 144 Friends to the House of Commons in $1659,{ }^{2}$ in which they asked not for the release of Quaker prisoners but for permission to replace them, one for one.

With this knowledge, the early satires like Butler's Hudibras seem like justifications of Royalist policy. We also note that the Restoration satirists appear to omit deliberately distinctions and intolerance among the Dissenting sects, Butler for example by his incongruous pairing of a Puritan colonel and a Quietist squire. No one would guess from Hudibras that the religious conflict went outside Anglican vs Puritan.

To bridge the years between Butler and Centlivre, let us summarize. In 1689 the Toleration Act was passed, but Nonconformists were banned from universities and professions until 1828. Quakers continued to be fined, imprisoned and to have their goods seized for refusal to pay tithe well into the 19th century.

Turning to Centlivre, A Bold Stroke for a Wife was first produced in 1718 , and while fairly popular in the 1720 s- 40 s it became very popular in the late 1750 s and was still played in the 19 th century. The plot briefly is that Colonel Fainwell must deceive four diverse and eccentric guardians into giving consent before he can marry the heiress Ann Lovely. One of these four is the Quaker Prim, who appears with his wife and household.

The Prims are usually considered examples of the Quaker as stock dramatic type, for example by F.P. Lock. ${ }^{3}$ Maxfield's article, 'Quakers in English plays 1680 - 1800,' sums up this characterization on which Centlivre draws and to which she adds. The ordinary Englishman, not 
understanding why the Quakers refused conventional courtesies, deemed them 'ignorant, ill-mannered, and ridiculous' (p. 258, and in Defoe's True-Born Englishman). Maxfield, in his survey, finds a general failure to distinguish Quakers from other sects in the language, behaviour and even dress (beyond hats) attributed to them (pp. 263-64). 'Inner light' seems to be almost the only phrase consistently and correctly put in the mouth of a stage Quaker. Refusing oaths and advocating pacifism subjected Quakers to considerable criticism as disloyal to King and country. Maxfield concludes that while playwrights make fun of the obvious peculiarities - from plain dress to single-prices to the inner light - 'his real character they do not know or care to know, any more than his motives. His language they miss woefully, even in the rare instances when they treat him fairly.' (p.272) Maxfield sees the caricature, but attributes no motive to the playwright beyond seeking to meet the audience's expectations (p. 273).

Susannah Centlivre was a well-known Whig and anti-Catholic, a minor player in the Alexander Pope satires, ${ }^{6}$ lampooned in Three Hours after Marriage and the Dunciad, possibly replying by a dig at Pope in this play Act III. Centlivre's anti-Catholicism naturally extended to Quakers, a frequent association in view of William Penn's friendship with the Catholic James II.

In $A$ Bold Stroke, the Quaker dress is subject to constant attack in the play: 'I ever thought, indeed, there was more design than godliness in the pinched cap' (Ann Lovely; $V, i){ }^{7}$ The Quaker costume we recognize from oatmeal boxes, and satirized here, is simply the ordinary middleclass clothing of the Commonwealth, maintained by the Quakers after the Restoration. ${ }^{8}$ It provoked more than ridicule. Thomas Chalkey (16751741) writes in his journal:

When between 8 and 10 yrs of age...I went mostly by myself to the school; and many and various were the exercises I went through, by beatings and stonings along the street, being distinguished to the people (by the badge of plainness which my parents put upon me) of what profession I was; divers telling me 'twas no more sin to kill me than it was to kill a dog. ${ }^{9}$

Sexual hypocrisy, linked to the overly modest dress, is not discussed by Maxfield, but is a 'common dramatic theme' according to F.P. Lock (p. 111), and certainly a constant in this play. Prim avidly pursues his housemaid (II ii), an implausible target since Quaker servants attended meetings with their employers and were quite free to confess publicly, subjecting Prim to the discipline of the elders. Add to this that any marriage outside the Meeting meant exclusion from it, and the Prims' 
concern that Ann marry a Friend seems less selfish, their forgiveness of a son dallying with a Quaker servant less immoral (II,ii). It is also outside Quaker tradition to impose guardians and conditions on marriage; in Quaker marriages the two individuals take each other, there is no father giving this woman to this man. To marry against conscience would be tantamount to sin.

Fainwell succeeds in convincing the Prims he is the real Simon Pure from Philadelphia by his dress and because he can imitate the Quaker idiom more convincingly than Pure can speak it.' (Lock, p. 110) Lock does not ask if Centlivre can write the Quaker idiom convincingly. In any case the key trait of Quaker worship is not speech, not the mastery of a cant vocabulary but silence. George Whitehead (1636-1722) in his Journal: 'Being much inwardly exercised in waiting upon the Lord among them, where we had little preaching, but our meetings kept much and often in silence, or but few words declared. ${ }^{10}$ Centlivre could not put on stage a genuine Quaker meeting for worship, which would normally begin with up to an hour of complete silence and which would not likely take place in the Prims' house. One doubts whether even Fainwell could carry off the extended silence and the impersonation in front of a large group of elder Quakers.

Lock considers Prim and Tradelove (two of the satirized guardians) as well as Freeman (Fainwell's ally) all as representing the mercantile, whiggish class praised by Centlivre and opposed to the conservative Sir Philip and Periwinkle (pp. 111-113): 'One merchant is of more service to a nation than fifty coxcombs. The Dutch know the trading interest to be of more benefit to the state than the landed' $(\mathrm{V}, \mathrm{i})$.

Let us then examine the role of Quakers in English commerce. Here the key source is Isabel Grubb's Quakerism and Industry before 1800. The Society functioned as a complete community, overseeing and trying to improve the commercial as well as the private behaviour of its members (Grubb, p. 148), acting as arbitrator to avoid litigation between members (Grubb, p. 81). The frequent warnings against debt and speculation, the practical and financial support of the meeting to its members, the avoidance of dealings with persons prone to debt or litigation all contributed to their ability to build up capital (Grubb, p. 175). As well Quakers had an enviable reputation for honesty, and refused to bargain; they invented the practice of price tags. Let us remember also that the Quakers were a closed group, marrying among themselves; marrying outside, ie in the Anglican church, led to disownment. In the society at large resentment of that to which one cannot have access is not surprising.

The Quakers were in fact dominant in the iron and coal industries of the 18th century - the Darbys, the Lloyds - and moved from trade into 
banking - Lloyds and Barclays. Rowntree, Fry and Cadbury were all Quaker family firms in this period.

Concern among Quakers for work conditions and poor relief dates back to 1668 (Grubb, pp. 71-72, 136-37, 157-160): apprenticeships, better workhouses and prisons, housing for workers. Quaker employers exhibit 'substantial improvements' over their competitors (Grubb p. 160). Quakers were counselled to avoid trades where the use of the product (ie silversmithing, bookselling, gunmaking) or the work conditions (ie cotton mills) were against conscience (Grubb, p. 176). Thus the Quakers were not only very successful merchants and bankers, they were able to compete while improving conditions for employees and avoiding compromises with the munitions or fancy-goods trade. A bitter pill for the strongly Anglican mercantilist Centlivre to swallow.

Centlivre's patriotism is inseparable from her militarism; Fainwell's speech closing the play neatly combines them:

I have had the honor to serve his Majesty and headed a regiment of the bravest fellows that ever pushed bayonet in the throat of a Frenchman; and notwithstanding the fortune this lady brings me, whenever my country wants my aid, this sword and arm are at her service.

The Quakers were firm upholders of pacifism: the statement made by the Quakers to Charles II in 1661 was adopted as one of their 'testimonies,' positions one takes if one is a Quaker:

All bloody Principles and Practices we (as to our own particular) do utterly deny, with all outward wars and strife and fightings with outward Weapons, for any end, or under any pretext whatsoever.....And we do certainly know, and so testify to the World, that the Spirit of Christ which leads us into all Truth, will never move us to fight and war against any man with outward Weapons, neither for the Kingdoms of Christ, nor for the Kingdoms of this World. ${ }^{11}$

Note that this is not only a statement of unequivocal pacifism but a clear rejection of the idea that war can be justified by religion, and thus a blow at the Anglican attitude of fighting for God and England. It was understood, however, as disloyalty and cowardice.

Lock feels that the satire in $A$ Bold Stroke is gentle, directed against types (p. 113), and 'less at the occupational group which they represent than at narrowmindedness and social intolerance in general' (p. 116). So Centlivre advocates tolerance? Perhaps, provided that the appearance 
of conformity to general norms in dress, language, politics and religion are maintained.

Was Centlivre expressing her own feelings or those of her audience? Public attitudes to Quakerism at this time are hardly more liberal. Stephen Hobhouse details the struggle of a young woman who wished to leave the Church of England for the Quakers in 1736. This was fought strenuously by her family, who confined her to a country house, intercepted her mail, and enlisted William Law, 'the best known religious writer in England' to dissuade her. ${ }^{12}$ Interestingly enough they failed, and she became not only a Quaker but a travelling Friend (pp. 162-63). This aspect of Quaker worship - the equal access and equal authority of women in the spoken ministry - never failed to provoke opposition and ridicule, from Law as elsewhere (p. 255). The woman preacher who surprised Samuel Johnson was a Quaker. One is surprised that the undoubtedly feminist Centlivre, who presents Ann Lovely as not only choosing her own husband but active in enabling their marriage, was in no way attracted to the greater freedom afforded to women in the Quaker society.

When we look to Voltaire, the two constant questions are why he chose to describe the Quakers, who were among the smaller Nonconformist sects, and how he uses them in the argumentation of the Lettres. According to Dennis Fletcher, it was the 'singularity of their beliefs and behaviour...their value chiefly as a model but also, in some respects, as a cautionary example' which motivated the choice; 'the tolerance of the Quaker congregation mitigates the absurdity of this spectacle ${ }^{\prime 13}$ that is of Meeting for Worship. Our reading of Centlivre and Butler suggests that the tolerance is more apparent than profound, consisting chiefly in the absence of legalized physical violence.

Letters I - IV on the Quakers with Letter XXV the Anti-Pascal form a frame around the Lettres philosophiques, linked by the rejection of religious philosophy for rationalism. Thus we expect Voltaire to give short shrift to inspiration and personal mystical experience. Voltaire rejects the Quakers as he rejects Pascal, for prizing mystical and personal experiences over rational ethics (Fletcher, p. 51). Voltaire seems equally disgusted by the belief in direct inspiration as by the equality of ministry it permits; he has the Quaker rank speakers downwards from foolish men to women, which is not at all the Quaker position on women in the church. ${ }^{14}$ His portrayal of the worshippers as contortionists is equally incorrect, as André Michel Rousseau points out in his work on Voltaire in England. ${ }^{15}$

Voltaire's primary goal in the Lettres philosophiques, critics agree, is to criticize Catholicism. The Quakers, with their rejection of hierarchy and sacrament form the ideal contrast. Sareil emphasizes the inability of the 
supposedly Catholic narrator to refute Quaker arguments. The tolerance with which they are treated and with which they treat others is perhaps the value Voltaire most wishes to emphasize, against the brutal intolerance towards both protestantism and jansenism of the French Catholic Church in the 18th century.

Fletcher, following Pomeau, brings out the sympathetic nature of the portrayal:

Voltaire ... gives the Quakers due credit for their staunch pacifism, spirit of charity, tolerance and brotherly love, practical concern for man's essential duties, respect for the laws of the land and determination to get on in the world....His ultimate ideal may well be mirrored in the idyllic, Arcadian society of Pennsylvania, which will be recalled by the utopian Eldorado of his Candide.

(p. 21)

Voltaire admires primarily what the Quakers have in common with his own values.

Sareil on the other hand finds little sympathy and less realism in the Lettres, rejecting the traditional view, held by Rousseau for example, that the merchant in Lettres I and II is a recognizable portrait of the Quaker Andrew Pitt. The Quakers are merely useful puppets in this didactic comedy: 'un climat ludique sans lequel cette propagande perdrait beaucoup de son efficacité, ${ }^{16}$ chosen precisely because they are ridiculous ( $p$. 279). Sareil also disagrees with Fletcher and Pomeau by refusing the idea that Voltaire's true opinion of the Quakers whether favourable or not can be found in the Lettres (p. 279). He feels that 'les bons Quakers' should be grateful to Voltaire for giving them free of charge, 'une extraordinaire publicité' (p. 286), rather than asking pointed questions about the objectivity of this portrayal or being insulted by the dismissal of Fox as a charlatan.

However, Sareil does give a clear explanation of how Voltaire makes the Quakers, or indeed any target of his satire, seem ludicrous: he describes only the exterior action and omits all significance attached thereto (pp. 281, 284-5). Quaker preaching becomes: 'on tremblait, on parlait du nez, on avait des convulsions, et on croyait avoir le Saint-Esprit' (Letter III), Anglican baptism: 'jeter de l'eau froide sur la tête avec un peu de sel' (Letter I).

It would appear as much a surprise to twentieth-century critics as to Voltaire that the Quakers, so generally believed in the 18th century to be in full decline, are still in existence. Voltaire sees the passivity of the Established Church, combined with its grip on privilege, as the means of this quiet assimilation: 'Par tout pays, la religion dominante, quand 
elle ne persécute point, engloutit à la longue toutes les autres' (Lettre IV, end). Fletcher feels that Voltaire has a 'basically sound analysis of the decline of Nonconformity' (p. 17). Sareil also refers in the present tense to the decline of the Quakers (p. 286). Today the Society of Friends has more than a million members and attenders from London to Australia, with the largest groups in the United States and in East Africa.

What does not appear in Centlivre for obvious reasons nor in Voltaire by ignorance or omission is the active social criticism and reform among the Quakers. While the Quakers might live outside the mainstream, they were by no means passive or silent about it. England, specifically London, in the late 17th to 18th centuries was crowded, unsanitary, violent, and prone to riots, populated by a few rich and hordes of poor (many of whom were deserted children), where capital punishment was imposed for minor offenses, which permitted imprisonment and execution of children from the age of 12 , and which was faced already with rising alcoholism in that gin was cheaper than food by the early years of the 18th century. ${ }^{17}$

In 1688 American Quakers record the first protest against slavery with growing support until 1761 when London Yearly Meeting resolved to disown slave-owning Quakers. American Quakers were very active in the Underground Railroad, and helping in resettlement (Brinton, pp. 76-86), including the real-life Eliza of Uncle Tom's Cabin.

In education, the Quakers established schools for the poor as well as for themselves, and 'workhouses' which tried to be trade schools and/or employers: Bristol 1696 Clerkenwell workhouse, Saffron Walden, Ackworth school 1779 (Grubb pp. 140-42; Hubbard, p. 43). From 1671 London's Six Weeks Meeting made itself responsible for the care of poor Friends and those coming to the Meeting for assistance (Bellers, p. 4). Parliament, on the other hand, supported a policy of subsistence wages - only fear of starvation could keep workers to the long hours required, and low wages kept export prices down (Bellers, pp. 10-11; a view argued by Defoe).

Quakers founded the first 'modern' mental hospital in 1796 - kindness and rehabilitation rather than confinement and violence (Hubbard, p. 45). Quaker involvement in prison reform dates back to the 1660 s and 1670s, with the best known activist being Elizabeth Fry in the early 19th century, who brought visitation, literary and skills education to the women in Newgate. The society is still active and still bears her name (Grubb, pp. 136-37).

Perhaps the clearest articulation of these reformist goals lies in the work of John Bellers, published in the 18th century and much discussed in Quaker circles. Bellers was born to Quaker parents and was a close friend of William Penn. Quoting Clarkes' introduction to Bellers, 'He 
was one of the most radical thinkers of his day, and saw with stark clarity the vital relationship between crime, poverty, ill-health, unemployment and lack of education; all were symptoms of one massive problem - a grossly maladjusted social and economic system' (Bellers, p. 17). In his writings, all pre-1720, we find proposed national free education and health care, prison reform, the abolition of capital punishment and the formation of a European league of nations (pp. 18, 20-24). Bellers was rediscovered in the early 19 th century by Robert Owen and later by Marx through Owen. Through Marx Bellers became quite well known in Europe and remains on the curriculum of Eastern Bloc schools (pp. 26-28).

\section{CONCLUSION}

In this necessarily brief survey of the Quakers both in the literature of the 18th century and in their own writings, we have seen nonetheless how subjective the well-known portraits are, incomplete and skewed by bias so that they might better play the role defined for them by the author. Hudibras takes on a new, darker edge in its context of systematic persecution. A Bold Stroke, fifty years later, is hardly more tolerant. Centlivre suspects the Quakers of disloyalty to King and country; they were rivals to 'honest Englishmen' in business, threats to national security, and presumptuous rebels against the Established Church. She ridicules their dress and language as mere veils for self-interest and lasciviousness. Her errors and distortions in describing Quaker practices and beliefs are numerous. Even the names chosen demonstrate Centlivre's parti pris. The Prims, personifying hypocrisy, are used primarily as a foil for the wit and courage of Fainwell, the virtue and independence of Ann Lovely, the genuine friendship and honesty of Freeman. Voltaire's portrayal, while on the surface more favourable, is no more disinterested. Sareil rightly calls the Quakers marionnettes in Voltaire's comedy of propaganda. Centlivre at least takes the Quakers seriously; far from disappearing quietly into the mainstream, they undermine the status quo. Voltaire's attitude, in so far as it can be discerned is primarily amusement; their leaders he dismisses as charlatans or sincere fools. While praising the values they share with him, he shows very little of the religious tolerance he admires for the personal, mystical relationship with God which to the Quakers is the source of all their social endeavors. I have introduced, there is not time to do more, the major Quaker writers - John Bellers, George Fox, George Whitehead and some historians - Howard Brinton, Isabel Grubb. Robert Barclay's Apology, to which Voltaire makes reference, is still widely available; 
William Penn is a wellknown name, if not more. We cannot adequately judge the literary images of Quakers, however sure we may be that they are polemic and satirical, if we do not seek out the social and philosophical realities which motivated these caricatures. It would be as unsound as judging the role of blacks or native Indians in North American society solely by Amos n' Andy and the Lone Ranger.

\section{HOPE LEITH}

University of British Columbia

\section{Notes}

1 Isabel Grubb, Quakerism and Industry before 1800 (London: Williams \& Norgate, 1930), p. 108.

2 Quoted by Geoffrey Hubbard, Quaker by Convincement (Harmondsworth: Penguin, 1974), pp. 37-38.

3 F.P. Lock, Susanna Centlivre (Boston: Twayne, 1979), pp. 28, 109.

4 E.K. Maxfield, in PMLA 45 (1930): 256-273.

5 Maxfield's two examples both come from Centlivre plays; see also Lock, p. 126.

6 Lock, p. 29; J.W. Bowyer, The Celebrated Mrs. Centlivre (Durham, NC: Duke UP, 1952), pp. 204-206.

7 All quotations from $A$ Bold Stroke for a Wife by Centlivre come from Thalia Stathas' edition in the Regents Restoration Drama Series (Nebraska UP, 1968).

8 Howard H. Brinton, Quaker Journals: Varieties of Religious Experience among Friends (Wallingford PA: Pendle Hill, 1972), p. 53.

9 Quoted on p. 2 of Brinton, taken from Journal or Historical Accounts of the Life, Travels, and Christian Experience (Philadelphia: James Chattin, 1754).

10 Published in 1725, quoted by Brinton, p. 10.

11 From the Journal of George Fox (Cambridge UP, 1952), pp. 399-400, cited in Hubbard and in Christian Faith and Practice.

12 Stephen Hobhouse, William Law and Eighteenth-Century Quakerism (New York: Macmillan, 1928), p. 23.

13 Dennis Fletcher, Voltaire: Lettres philosophiques (London: Grant \& Cutler, 1986), p. 20.

14 Letter II, Lettres philosophiques ed. René Pomeau (Paris: Garnier - Flammarion, 1964). All quotations from the Lettres will be from this edition.

15 André Michel Rousseau, L'Angleterre et Voltaire, tome I, SVEC CXLV (1976), p. 135.

16 Jean Sareil, 'Les quatres premières Lettres philosophiques,' Romanic Review LXXVI (1985), p. 278. 
17 George Clarke, John Bellers: His Life, Times and Writings (London and New York: Routledge \& Kegan Paul, 1987), p. 14. This work will be referred to in the body of the text as Bellers.

\section{Bibliography}

\section{Quakers}

Brinton, Howard H. Quaker Journals: Varieties of Religious Experience among Friends. Wallingford PA: Pendle Hill, 1972.

Christian Faith and Practice in the Experience of the Society of Friends. London Yearly Meeting, 1972.

The most recent collection by the Society of Friends (the first dating from 1738) of extracts from Quaker writings, journals, correspondences, minutes of meetings, etc., primarily English. Date and author are indicated when known, both in the text and in the index. There are also subject and proper name indexes, and a full list of sources and references, numbering more than 600 .

Clarke, George. John Bellers: His Life, Times and Writings. London and New York: Routledge \& Kegan Paul, 1987.

Grubb, Isabel. Quakerism and Industry before 1800. London: Williams \& Norgate, 1930.

Hobhouse, Stephen. William Law and Eighteenth-Century Quakerism. New York: Macmillan, 1928.

Hubbard, Geoffrey. Quaker by Convincement. Harmondsworth: Penguin, 1974.

\section{English Literature}

Bowyer, J.W. The Celebrated Mrs. Centlivre. Durham, NC: Duke UP, 1952.

Butler, Samuel. Hudibras, ed. John Wilders. Oxford: Clarendon, 1967. See also the introduction to Butler in the Norton Anthology of English Literature, vol. I (1979).

Centlivre, Susanna. A Bold Stroke for a Wife, ed. Thalia Stathas, Regents Restoration Drama Series. University of Nebraska Press, 1968.

Lock, F.P. Susanna Centlivre. Boston: Twayne, 1979.

Maxfield, E.K. 'The Quaker in English Plays before 1800,' PMLA 45 (1930): 256-73.

With a correction from Bowyer regarding $A$ Bold Stroke on pp. 957-958 of the same volume. Maxfield seemed unaware that The Guardians Over-Reached in their Own Humour was a 1740s two-act adaptation of $A$ Bold Stroke, and does not mention the earlier play.

\section{Voltaire}

Fletcher, Dennis. Voltaire: Lettres philosophiques. London: Grant \& Cutler, 1986.

Pomeau, René. La Religion de Voltaire. Paris: Nizet, 1969. 
Rousseau, André Michel. L'Angleterre et Voltaire, tome I. SVEC CXLV, 1976.

Sareil, Jean. 'Les quatres premières Lettres philosophiques,' Romanic Review LXXVI (1985): 277-86.

Voltaire. Lettres philosophiques, ed. René Pomeau. Paris: Garnier-Flammarion, 1964. 